Явище полісемії включає дуже багато аспектів і вимагає набагато глибшого дослідження, тому необхідно підкреслити, що питання створення комплексного підходу до вивчення такого явища в лексикології як полісемія представляється цікавим і особливо злободенним нині в зв'язку із величезною кількістю багатозначних слів в різних мовах.

\title{
Лiтература:
}

1. Виноградов В.В. Основные типы лексических значений слова. Избранные труды: Лексикология и лексикография. Москва: 1977. C. $162-169$.

2. Амосова Н. Н. Фразеология английского языка. Москва: Ленинградский. университет, 1963.98 с.

3. Бархударов Л. С. Язык и перевод (вопросы общей и частной теории перевода). Москва: Международные. отношения, 1975. 275 с.

DOI https://doi.org/10.30525/978-9934-26-073-5-2-28

\section{PSYCHOLINGUISTIC ASPECT AS THE LATEST AND SIGNIFICANT COMPONENT OF MODERN TRANSLATION STUDIES}

\author{
Karachova D. V. \\ Candidate of Philological Sciences, \\ Senior Lecturer at the Department \\ of Business Foreign Language and Translation \\ National Technical University «Kharkiv Polytechnic Institute»
}

\section{Prytychenko H. V.}

Lecturer at the Department of Business Foreign Language and Translation National Technical University "Kharkiv Polytechnic Institute» Kharkiv, Ukraine

Psycholinguistics, as a scientific field, appeared not so long ago, in the twentieth century, but has already brought some scientific achievements.

The topic of psycholinguistic studies is quite relevant and each day it is more and more in demand so many scientists work in this field of linguistic research. Among modern scholars who work in this sphere of translation we can mention such names as Kovshikov V.A. [1], Leontiev A.A. [2], 
Piven N.M. [3], Rebrii O.V., Rebrii I. M. [4], Frumkina R. [5], Field J. [6], Hatzidaki A. [7], Slobin D. [8], etc.

Various psycholinguistic studies are extremely relevant today, because they are a combination of two or more scientific fields, and make it possible to comprehend and explain the specifics details of the translation process and its features. It is important to admit that in the process of studying translation process, one cannot ignore the psychological factor of a person, because translation is not only a person's speech activity, but also a reflection of his ther mental health, which bears the imprint of the psychological component and worldview of the translator. The subject of research of psycholinguistics is first of all language activity as a special type of human activity, its psychological content, structure, types (ways) in which it is carried out, forms in which it is realized, functions performed by it. As the researcher and founder of the national school of psycholinguistics $\mathrm{O}$. Leontiev notes: «the subject of psycholinguistics is a language activity itself and the laws of its complex modeling» [2, p.65]. Psycholinguistics is closely related to translation studies; it clarifies it and contributes to more detailed research. Translation is a special type of communicative behavior, a process of communication, whether it is written or oral translation, which involves not only hearing ability, knowledge and understanding of a foreign language, but to a large extent the psychophysiological characteristics of a person who perceives a foreign language. Therefore, the mental aspect of translation can and should be the subject of research. It is psycholinguistics designed to study language as a psychological phenomenon, to «reveal» the work of the translator, his real actions on a psychological level. Psycholinguistics offers a comprehensive approach to the study of such phenomenon as translation as the object of study of psycholinguistics and translation theory is general - language activity. Thus, as we can see, the combination of many components makes psycholinguistic research extremely difficult and comprehensive to study [6, p. 127].

Nowadays there are many approaches and principles of studying human speech activity. Among the most relevant are the following:

- the first principle - the integrity of language activities.

It is characterized by a combination of all, or some, forms of language in the language process. Here is an important integrity of language activity, which is the mandatory interaction of all components of its operations (semantic, syntactic, lexical, morphological, morpho-syntactic, phonemic and phonetic), all stages and levels of the language process.

- the second principle - the defining value of linguistic semantics.

This principle is characterized as the conditionality, subordination of all components of speech activity to the meaning and content of products and 
results of this activity. Linguistic activity is aimed at extracting (in the perception of language) or creating and transmitting (in the generation of language) the meanings of language signs (universal meanings) and meanings (personal, individual meanings).

- the third principle - the inseparable connection of speech activity with the individual.

This principle is characterized by a certain complexity and ambiguity. Its characteristics must take into account the level of organization of the individual («higher» - worldview, ideals, social orientation, etc.; «middle» character, features of mental processes, etc., «lower» - emotions, temperament, etc.) and which component of this level comes into contact with a certain component of language (for example, lexical, phonetic, etc.). Therefore, certain components of a particular level of personality may correlate with other components of language, and others - no. Here the activity influences mainly because both the process of speech generation and the process of its perception can occur and acquire appropriate characteristics only with the activity of the individual (mental, intellectual).

- the fourth principle is genetic.

This principle can be characterized by the fact that at different ages a person masters various forms of language (first - oral and «kinetic», then written) and various operations of speech activity (first «primitive», then complex), the characteristics of which change during human life [4, Pp. 182-184].

The problem of language translation from the standpoint of psycholinguistics is the question of how the process of expressing the same thoughts by a translator by means of two different languages, the process of switching thinking from one language to another. Therefore, translation is not considered a special kind of speech, but a special kind of mental process. In other words, the question of translation as a psycholinguistic aspect is directly related to the interaction of language and thought.

Recently, a lot of attention has been paid to so-called psycholinguistic models and approaches, which are based on the understanding of translation as a speech activity and which reflect the real actions of the translator, who first realizes the source material and forms his own understanding of this material. The translation process consists of two stages: understanding and translation. These two interdependent stages of the translation process differ in the nature of language actions. Firstly, the translator must analyze the information of the original text, and then there is a translation process of selecting the necessary language units to reproduce the original text. 
Thus, the psychological approach plays an important role in the first stage of translation, which focuses on the study of the translation process, the study of the «human component» in translation, the analysis of the psychology of the translator's choice of certain solutions in difficult situations. In order to reflect more fully the mental processes of the translator's activity that the psycholinguistic model of translation is studied, which considers translation as a two-stage process: the translator's transformation of his understanding of the original content into his internal program; the psycholinguistic translation model is not only based on the theory of language activity, but also fully reflects the real actions of the translator, describing all the processes that ensure the work of the translator at the psychological level. Psycholinguistics is an invaluable tool for analyzing the communicative process from the acoustic-physiological and linguistic sides.

\section{References:}

1. Ковшиков В.А. Психолингвистика. Теория речевой деятельности. Москва, 2006. 220 с.

2. Леонтьев А.А. Основы психолингвистики. М.: Смысл, 1999. 287 с.

3. Півень, Н. М. Психолінгвістичні аспекти перекладу: навч. посібник / Н. М. Півень, ПДТУ. Каф. українознавства. Маріуполь: ПДТУ, 2014. $60 \mathrm{c}$.

4. Ребрій О., Ребрій І. Системність і творчість у перекладі: психолінгвістичний підхід. Psycholinguistics. 2018. Вип. 23., № 2. C. 180-191.

5. Фрумкина Р.М. Психолингвистика. Москва, 2001. 320 с.

6. Field J. Psycholinguistics - The Key Concepts. London: Routledge, 2004. 387 p.

7. Hatzidaki, A. The Process of Comprehension from a Psycholinguistic Approach - Implications for Translation. 2007. Meta, 52 (1), P. 13-21.

8. Slobin D.I. Psycholinguistics. Berkeley: University of California, 1972. $351 \mathrm{p}$. 